\title{
Toll Like Receptor 2 Genotypes and Intra-Coronary Stent Restenosis
}

\author{
TAREK ABDELAZIZ, M.D.*; RANDA HUSSINY, M.D.**; MARWA GAD, M.D.* and \\ MOHAMED GAMEL, M.Sc.* \\ The Departments of Cardiology* and Medical Biochemistry**, Faculty of Medicine, Zagazig University
}

\begin{abstract}
Background: Intra-coronary Stent Restenosis (ISR) is a common complication after Percutaneous Coronary Intervention (PCI). There is an association between many genes such as Toll Like Receptor 2 (TLR2), Adrenergic B2 Receptor (ADRB2), platelet glycoprotein IIIa, Nitric Oxide Synthase3 (NOS3), P2Y12 receptor (P2Y12), cyclin-dependent kinase inhibitor ( $\left.\mathrm{p}^{2} \mathrm{k} \mathrm{kip}^{1}\right)$ and the process of intra-coronary stent restenosis. Study of the genetic polymorphisms of these genes is very important to detect which is protective against intracoronary stent restenosis, and which is risky for development of this problem. Our study selected TLR2 gene to detect its different genotypes involved in the problem of ISR.
\end{abstract}

Aim of Study: To find the association between TLR2 genotypes, polymorphisms and Intra-coronary Stent Restenosis (ISR) complication after PCI procedures.

Patients and Methods: The study included 200 patients with previous coronary revascularization by stent implantation. All patients were re-admitted to coronary angiography because of objective evidence of myocardial ischemia. The patients were classified into two groups: Group (A) included 100 patients who developed ISR and Group (B) included 100 patients who did not develop ISR. The two groups were compared regarding distribution of TLR2 genotypes and alleles.

Results: $78 \%$ of patients with (GG) genotype, $14 \%$ of patients with (GA) genotype and $7 \%$ of patients with (AA) genotype developed ISR. There was no association between TLR2 (GA), (AA) genotypes and risk of ISR when compared by $(\mathrm{GG})$ wild homozygous genotype $(p>0.05, \mathrm{OR}=1.2)$. We also did not find any association between TLR2 gene alleles and risk of ISR complication $(p>0.05, \mathrm{OR}=0.9)$.

Conclusion: There was no association between different TLR2 genotypes, alleles and risk of ISR development.

Key Words: ISR: Intra-coronary Stent Restenosis - PCI: Percutaneous Coronary Intervention - TLR2: Toll Like Receptor 2.

Correspondence to: Dr. Tarek Abdelaziz, The Department of Cardiology, Faculty of Medicine, Zagazig University

\section{Introduction}

INTRA-CORONARY Stent Restenosis (ISR) is a known problem after Percutaneous Coronary Interventions (PCI) [1]. Restenosis is defined as gradual re-narrowing of the vessel lumen to $>50 \%$ at the site of previously implanted stent or up to $5 \mathrm{~mm}$ from the stent edges after percutaneous coronary interventions procedures [2]. Vascular damage induced by balloon inflation and stent placement during PCI is followed by platelet and leukocyte activation which release growth factors and cytokines that cause Smooth Muscle Cells (SMC) proliferation, extracellular matrix formation and neo-intimal hyperplasia resulting in restenosis [3] Some studies identified an association between many genes such as Toll Like Receptor 2 (TLR2), Adrenergic B2 Receptor (ADRB2), platelet glycoprotein IIIa, Nitric Oxide Synthase 3 (NOS3), P2Y12 receptor (P2Y12), cyclin-dependent kinase inhibitor ( $\left.\mathrm{p}^{27} \mathrm{kip} 1\right)$ and the process of intra-coronary stent restenosis [4]. Our study is established to detect the association between genetic polymorphisms of Toll Like Receptor 2 (TLR2) and the process of intra-coronary stent restenosis. TLR2 is a class of protein that plays a key role in the innate immune system [5]. As PCI induces vascular injury, the host may need the inflammatory response activated by TLR-2 for efficient local wound healing and prevention of restenosis. Mutation of TLR2 (Asp753Gln) may result in a nonfunctional TLR2 which will become unable to initiate the protective inflammatory process via this receptor, potentially resulting in more frequent restenosis of the coronary blood vessel at the site of implanted stent [6]

Aim of the study: To find the association between different TLR2 genotypes, polymorphisms and intra-coronary stent restenosis complication after PCI procedures. 


\section{Patients and Methods}

This study was carried out in the Cardiology and Medical Biochemistry Departments at Zagazig University in the period from March 2017 to March 2019. This study included 200 ischemic heart disease patients who were treated by coronary revascularization with stenting then re-admitted to coronary angiography because of recurrence of angina symptoms and positive non-invasive cardiac stress tests. The coronary angiography confirmed intra-coronary stent restenosis as re-narrowing of the vessel lumen to $>50 \%$ at the site of previously implanted stent or up to $5 \mathrm{~mm}$ from the stent edges [7] . Patients were excluded if they had intracoronary stent restenosis after primary PCI for acute ST-elevation myocardial infarction, ischemic attacks within 1 month after PCI and history of previous dye allergy during catheterization. The patients were classified into two groups: Group with intra-coronary stent restenosis and Group B with patent coronary stents each group included 100 patients. All patients were subjected to complete history taking, physical examination, laboratory tests for hyperlipidemia, and blood sugar level, twelve-lead surface ECG to detect ischemic changes, coronary angiography and genetic studies. Blood samples were taken from patients and collected in EDTA tubes at baseline then genomic DNA was extracted by following standard procedures [8]. Each DNA sample was amplified in multiple Polymerase Chain Reactions (PCRs) using biotinylated primers. The PCR product had been hybridized to a corresponding panel of sequencespecific oligonucleotide probes that had been immobilized in a linear array on nylon membrane strips [9]. Genotyping was performed by operators blinded to all patient data to detect the genetic polymorphisms of TLR2 gene involved in the problem of coronary stents restenosis [10]

Statistical analysis: Data collected throughout history, laboratory investigations, genetic studying entered to Microsoft Excel software for saving then imported into Statistical Package for the Social Sciences (SPSS) software for analysis. According to the type of data quantitative data were represented as number and percentage. The following tests were used to test differences for significance, difference and association of qualitative variables by Chi square test $\left(\mathrm{X}^{2}\right)$, risk by Odds Ratio (OR). $p$-value was set at $<0.05$ for significant results.

\section{Results}

According to genetic study of TLR2 gene in ischemic heart disease patients who were previously re-vascularized by coronary stenting, we found three variant polymorphisms to TLR2 gene; a wild homozygous (GG) genotype, heterozygous (GA) genotype and homozygous mutant (AA) genotype Fig. (1). This study compared both (GA) and (AA) genotypes with (GG) genotype to detect which genotype is protective against risk of intra-coronary stent restenosis and which is risky for development of intra-coronary stent restenosis. Patients with (GG) genotype and intra-coronary stent restenosis were 78 cases $(78 \%)$ and without intra-coronary stent restenosis were 83 cases $(83 \%)$. Patients with (GA) genotype and intra-coronary stent restenosis were 14 cases (14\%) and without intra-coronary stent restenosis were 12 cases (12\%). We reported that there was no association between TLR2 (GA) genotype and risk of ISR development ( $p>0.05$, $\mathrm{OR}=1.2$ ); patients with (AA) genotype and intracoronary stent restenosis were 7 cases $(7 \%)$ and without intra-coronary stent restenosis were 6 cases (6\%). There was no association between TLR2 (AA) genotype and risk of ISR development $(p>0.05, \mathrm{OR}=1.2)$ (Table 1). Regarding genetic alleles of TLR2 gene, patients with $(\mathrm{G})$ allele and intra-coronary stent restenosis were 167 cases $(83.5 \%)$ and without intra-coronary stent restenosis were 165 cases $(82.5 \%)$. We did not find any significant association between TLR2 gene's alleles and risk of ISR complication $(p>0.05, \mathrm{OR}=0.9)$. Fig. (2).

Table (1): Gene and alleles distribution between studied groups.

\begin{tabular}{|c|c|c|c|c|c|c|}
\hline & \multicolumn{2}{|c|}{ ISR } & \multicolumn{2}{|c|}{ NO } & \multirow{2}{*}{$\begin{array}{c}\text { OR } \\
\text { (CI 95\%) }\end{array}$} & \multirow{2}{*}{$\begin{array}{c}p- \\
\text { value }\end{array}$} \\
\hline & $\mathrm{N}$ & $\%$ & $N$ & $\%$ & & \\
\hline \multicolumn{7}{|l|}{ TLR2: } \\
\hline GG & 78 & 78 & 83 & 83 & & \\
\hline GA & 14 & 14 & 12 & 12 & $1.2(0.54-2.8)$ & 0.61 \\
\hline AA & 7 & 7 & 6 & 6 & $1.2(0.39-3.9)$ & 0.71 \\
\hline $\mathrm{G}$ allele & 167 & 83.5 & 165 & 82.5 & $0.9(0.55-1.6)$ & 0.79 \\
\hline
\end{tabular}

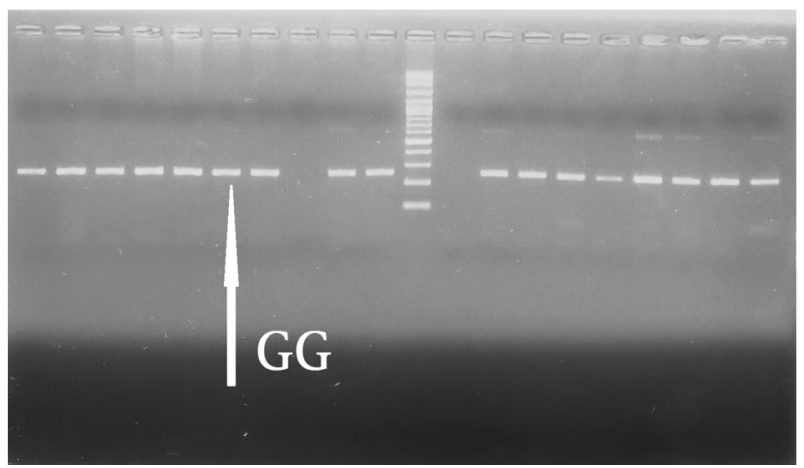

Fig. (1): Polymerase chain reaction assay for TLR2 homozygous wild (GG) genotype. 


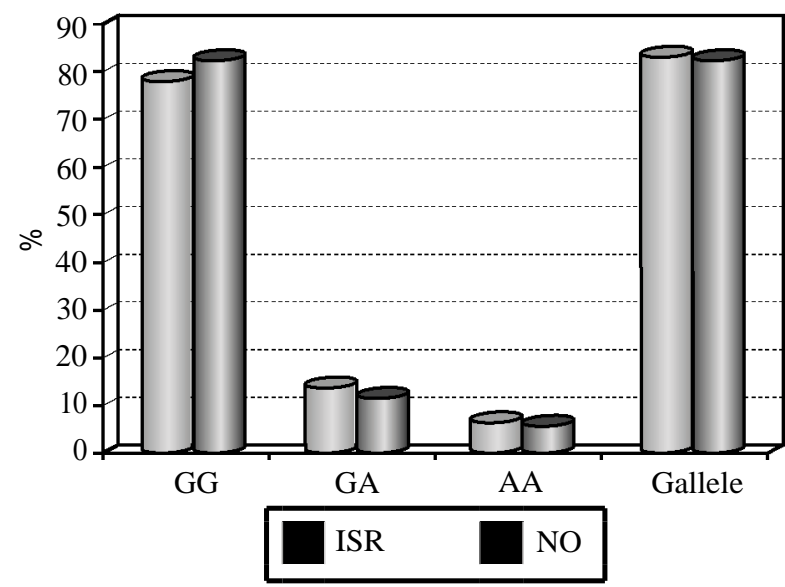

Fig. (2): Shows difference between both groups regarding TLR2 genotypes and alleles.

\section{Discussion}

Normally TLR2 (GG) genotype has a protective role against exaggerated inflammatory response induced by vascular injury during PCI procedures and prevention of intra-coronary stent restenosis [11]. Regarding other genotypes of TLR2 gene involved in the inflammatory process of intracoronary stent restenosis this study could not find any association between TLR-2 genetic polymorphisms and risk of ISR development after PCI procedures. These results were in disconcordance with Hamann and Gomma et al., 2005 who reported that frequent Single Nucleotide Polymorphism (SNP) for the TLR-2 gene, resulting in a nonfunctional receptor. They had found a significantly enhanced frequency of the TLR-2 Arg753Gln SNP in patients with restenosis when compared to those without restenosis [12]. Results of our study were against the results of Hamann and Gomma et al., 2005 study this probably due to type of the patients who are Egyptian and African in our study, but the other study included European patients who had a different community, life style and genetic characters. TLR-2 Arg753Gln Single Nucleotide Polymorphism (SNP) causes loss of TLR-2 function resulting in chronic development of atherosclerosis and restenosis as the host needs the inflammatory response activated by TLR- 2 for prevention of restenosis and efficient local wound, endothelial injury healing caused during stent implantation maneuvers such as balloon dilatation [13]. The results of our study were in concordance with Shuvalova and Kaminnyi et al., 2012 who reported that the endothelial Nitric Oxide Synthase (eNOS) genetic polymorphisms were associated with ISR in Chinese patients treated with Drug Eluting Stents (DES) while the TLR2 genetic polymorphisms were not associated with ISR in the same patients treated with DES. Genetic mutation of the eNOS inhibited the endothelial-derived nitric oxide biological effects which included vasodilation, inhibition of vascular Smooth Muscle Cells (SMC) growth, anti-atherosclerotic properties, prevention of platelet aggregation [14].

\section{Conclusion:}

There was no association between variant TLR2 genotypes or alleles and development of Intracoronary Stent Restenosis (ISR) complication after PCI procedures.

\section{Limitation:}

The high costs of genetic studies prevented us from increasing the sample size of patients who had a risk for development coronary in-stent restenosis complication after percutaneous coronary intervention procedures.

\section{Acknowledgment:}

We wish to express our gratitude to all the participant physicians and patients in this study.

\section{Conflicts of interest:}

No conflicts of interest declared.

Authors' contributions:

All authors had equal role in design, work, statistical analysis and manuscript writing. All authors have approved the final article work.

\section{References}

1- ALFONSO F., PEREZ-VIZCAYNO M.J., GARCIA DEL BLANCO B., OTAEGUI I., MASOTTI M., ZUECO J., et al.: Long-Term Results of Everolimus-Eluting Stents Versus Drug-Eluting Balloons in Patients With BareMetal In-Stent Restenosis: 3 Year Follow-up of the RIBS V Clinical Trial. JACC Cardiovascular Interventions, 9 (12): 1246-55, 2016.

2- EECKHOUT E., SERRUYS P.W., WIJNS W., et al. editors. Percutaneous Interventional Cardiovascular Medicine: The PCR-EAPCI Textbook. Europa Ed. PCR Publ., 785826, 2012.

3- CASSESE S., BYRNE R.A., SCHULZ S., et al.: Prognostic role of restenosis in 10004 patients undergoing routine control angiography after coronary stenting. Eur. Heart J., 36: 94-9, 2015.

4- OSADNIK T., STRZELCZYK J.K., REGULA R., et al.: The relationships between Polymorphisms in Genes Encoding the Growth Factors TGF- $\beta$ 1, PDGFB, EGF, bFGF and VEGF-A and the restenosis process in patients with stable coronary artery disease treated with bare metal stent. Wallace GR, ed. PLoS ONE, 11 (3): e0150500, 2016.

5- MAHLA R.S.: "Sweeten PAMPs: Role of Sugar Complexed PAMPs in Innate Immunity and Vaccine Biology". September, Front Immunol., 4: 248, 2013. 
6- BEIJK M.A., BOEKHOLDT S.M., et al.: Toll-like receptor 4 gene polymorphisms show no association with the risk of clinical or angiographic restenosis after percutaneous coronary intervention. Pharmacogenet Genomics, Sep., 20 (9): 544-52, 2010.

7- BASTANTE T., RIVERO F., BENEDICTO A., CUESTA J. and ALFONSO F.: Recurrent Neoatherosclerosis After Bioresorbable Vascular Scaffold Treatment of In-Stent Restenosis. J.A.C.C. Cardiovascular interventions, 8 (9): 1264-5, 2015.

8- LI P., ZHU N., YI B., et al.: MicroRNA-663 regulates human vascular smooth muscle cell phenotypic switch and vascular neointimal formation. Circ. Res., 113: 111727, 2013.

9- XU J., YU X., HUANG C., QIN R., PENG F., LIN J., et al.: Association of 5 Well-Defined Polymorphisms in the Gene Encoding Transforming Growth Factor- $\beta 1$ With Coronary Artery Disease Among Chinese Patients With Hypertension. Angiology, 66: 652-8, 2015.

10- ECKHOUSE S.R., JONES J.A. and SPINALE F.G.: Gene targeting in ischemic heart disease and failure: Translational and clinical studies. Biochem. Pharmacol., 85: 111, 2013.

11- YANG J., ZENG Y., ZHANG C., et al.: The prevention of restenosis in vivo with a VEGF gene and paclitaxel co-eluting stent. Biomaterials, 34: 1635-43, 2013.

12- HAMANN L., GOMMA A., SCHRÖDER N., STAMME C., GLAESER C., et al.: A frequent Toll-like receptor (TLR)-2 polymorphism is a risk factor for coronary restenosis. J. Mol. Med., 83: 478-85, 2005.

13- OTSUKA F., BYRNE R.A., YAHAGI K., MORI H., LADICH E., FOWLER D.R., KUTYS R., XHEPA E., KASTRATI A., VIRMANI R. and JONER M.: Neoatherosclerosis: Overview of histopathologic findings and implications for intravascular imaging assessment. Eur. Heart J., 36: 2147-59, 2015.

14- SHUVALOVA Y.A., KAMINNYI A.I., et al.: Association between polymorphisms of eNOS and TLR2 genes, activity of free-radical processes and in-stent restenosis. Mol. Cell Biochem., Nov., 370 (1-2): 241-9, 2012.

\section{الآنماط الجينية للمستقبل شبيه بالتول وعودة ضيق الدعامة

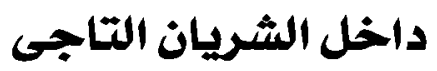

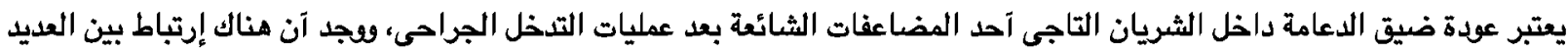

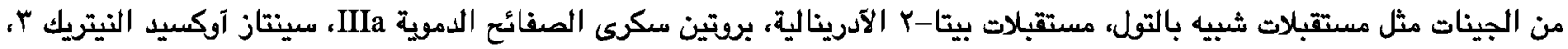

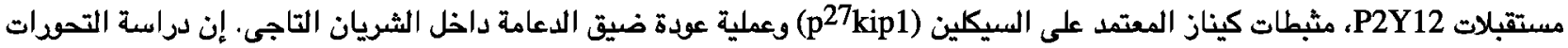

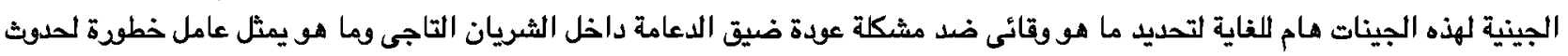

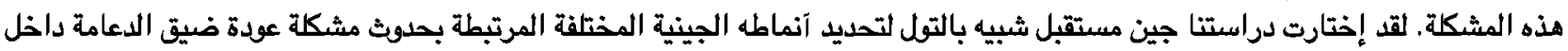

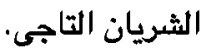

الهدف من الدراسة: إيجاد العلاقة بين الآنماط والتحودات الجينية المختفة المستقبل شبيه بالتول وحدوث مشكلة عودة ضيق الدعامة داخل

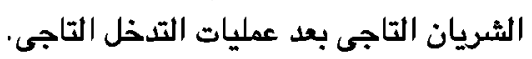

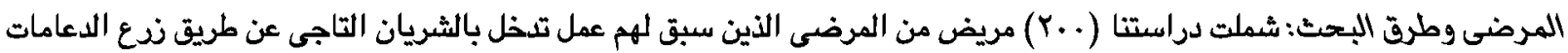

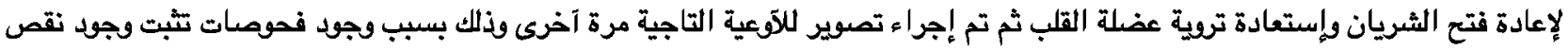

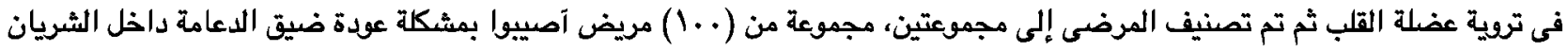

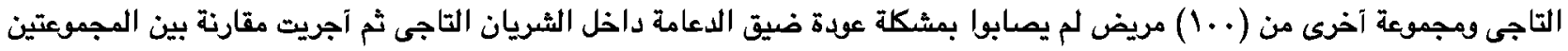
فيما يتعلق بتوذيع الآنماط الجينية والآليلات بين المجموعتين.

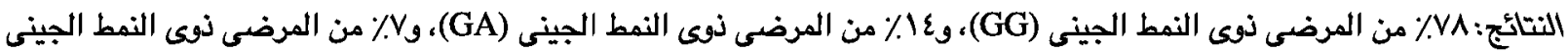

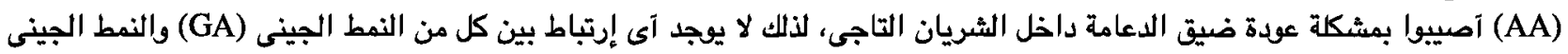

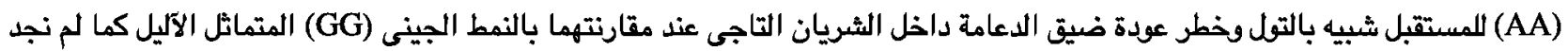

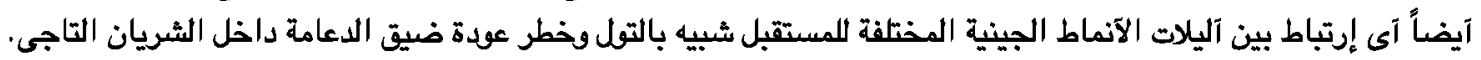

الإستتاج: لقد توصلت هذه الدراسة إلى آنه لا يوجد آى إرتباط بين آليلات والآنماط الجينية المختلفة للمستقبل شبيه بالتول وخطر عودة

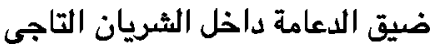

